\title{
Radioimmuntest zur Bestimmung von Humanmyoglobin: Untere Nachweisgrenze, Präzision, Verlaufskontrolle beim myoglobinuri- schen Nierenversagen
}

\author{
Von E. Kreuzfelder, E. Kuwert
}

Institut für Medizinische Virologie und Immunologie (Direktor: Professor Dr. Dr. med. E. Kuwert)

\section{R. Windeck, N. Graben}

Medizinische Klinik und Poliklinik, Abteilung für Nieren- und Hochdruckkranke

(Direktor: Professor Dr. med. K. D. Bock)

\section{K. Pistor und F. Heber}

Kinderklinik, Abteilung für Kindernephrologie (Direktor: Professor Dr. med. H. Olbing)

Universitätsklinikum der Gesamthochschule Essen

(Eingegangen am 15. September 1982/15. Februar 1983/30. September 1983)

Zusammenfassung: Bei einem Radioimmunoassay zur Bestimmung menschlichen Myoglobins wurde die Sensitivität als untere Nachweisgrenze mit Hilfe von 4 Verfahren bestimmt. Von den verwendeten Verfahren stellen 2 (90\%- und 3 s-Methode) „Präzision von Tag zu Tag“-Bestimmungen und die beiden übrigen (95\%Vertrauensbereich- und Methode von Markowetz \& Munz) „Präzision in der Serie“-Bestimmungen dar. Die untere Nachweisgrenze nach Markowetz \& Munz ist die niedrigste Myoglobinkonzentration, die bei 15-facher Messung weder einen Bindungswert mit denen der nächst größeren Konzentration noch einen Aktivitätswert mit denen des Bindungsbezugswertes gemeinsam hat. Diese Methode ist sowohl aus theoretischer („Präzision in der Serie") als auch praktíscher Sicht (Bestimmung der unteren Nachweisgrenze in einem Testansatz) am besten geeignet, die Sensitivität als untere Nachweisgrenze zu bestimmen. Es bleibt allerdings abzuwarten, inwieweit sich diese Aussage verallgemeinern läßt.

A radioimmunoassay for human myoglobin: Lower detection limit, precision, and use in following the course of myoglobinuric kidney failure

Summary: The lower detection limit of a radioimmunoassay for human myoglobin was determined by two "precision from day to day" methods ( $90 \%$ and $3 \mathrm{~s}$ methods), and by two "precision in series" methods (95\% confidence range and the method of Markowetz \& Munz). According to Markowetz \& Munz, the lower detection limit (as a measure of sensitivity) is the lowest myoglobin concentration which, in 15-fold assays, shows no binding value in common with that of the next highest concentration, and no activity value in common with that of the reference binding value. On theoretical grounds (precision in series) and from a practical standpoint (determination of the lower detection limit using one sample assay), this method is the most suitable for the determination of the lower detection limit as a measure of sensitivity. It remains to be seen whether this is a valid generalization for other methods. 


\section{Einführung}

Bei einem Radioimmunoassay (RIA) zur Bestimmung menschlichen Myoglobins wurden bereits mit einem modifizierten Testverfahren die Sensitivität, die damit zusammenhängende Wahl eines geeigneten Verdünnungsmediums, Präzision und Bestimmung des Myoglobins im Urin geprüft (1). Die Sensitivität definiert als untere Nachweisgrenze wurde zu $25 \mu \mathrm{g} / \mathrm{l}$ bestimmt ( $90 \%$-Bindung des myoglobinfreien Standards). In einer Reihe von Kinderseren war allerdings die Myoglobinkonzentration nicht quantitativ bestimmbar, da die Bindungswerte dieser Seren größer als die des $25 \mu \mathrm{g} / \mathrm{l}$-Standards waren. Diese Problematik war Anlaß dafür, eine niedrigere Nachweisgrenze für das Myoglobin zu erreichen, damit diese Kenngröße auch für die Diagnose und Verlaufskontrolle pädiatrischer Myo- bzw. Nephropathien anwendbar ist. Die vorliegende Arbeit beschreibt die Problematik, eine untere Nachweisgrenze zu definieren und die Methodik, die zu einer niedrigeren Nachweisgrenze führt. Ferner soll am Beispiel der Verlaufskontrolle eines myoglobinurischen Nierenversagens der Wert dieser Methodik demonstriert werden.

\section{Methodik}

Bestimmung von Myoglobin

Das Myoglobin wurde mit Hilfe eines Doppelantikörper-RIA's (Isotopen Diagnostik CIS, Dreieich) in einem modifizierten Testverfahren bestimmt (1). Die Konzentrationsberechnung erfolgte mit Hilfe von Standards, die aus dem $50 \mu \mathrm{g} / \mathrm{l}$ Myoglobin enthaltenden Standard durch Verdünnung mit Immunglobulinlösung in einer geometrischen Verdünnungsreihe unter Einbeziehung von entsprechenden Verdünnungen des myoglobinfreien Standards (Bindungsbezugswert) erhalten wurden. Es wurden nur solche Konzentrationen berücksichtigt, die nach logit/log-Transformation auf einer mit Hilfe der Regressionsanalyse erhaltenen Geraden lagen (Regressionskoeffizient $r \leqslant-0,92$ ).
Bestimmung der unteren Nachweisgrenze

3 s-Methode (3 s)

Die untere Nachweisgrenze ist diejenige Myoglobinkonzentration, die mit Hilfe des (Mittelwert der Aktivität des Bindungsbezugswertes - 3 Standardabweichungen (s))-Wertes berechnet wird.

$\cdot 1$

90\%-Methode (90\%)

Die untere Nachweisgrenze ist diejenige Myoglobinkonzentration, die mit dem $\mathbf{9 0 \%}$-Wert des Mittelwertes der Aktivität des -Bindungsbezugswertes berechnet wird.

95\% Vertrauensbereich-Methode (95\% VB)

Die untere Nachweisgrenze ist die niedrigste Myoglobinkonzentration, deren $95 \%$-Vertrauensbereich (VB) des Mittelwertes sich signifikant sowohl von dem der Aktivität des Bindungsbezugswertes als auch von dem der Bindungswerte der nächst größeren Konzentration unterscheidet.

\section{Methode von Markowetz \& Munz}

Die untere Nachweisgrenze ist die niedrigste Myoglobinkonzentration, die weder einen Bindungswert mit denen der nächst gröBeren Konzentration noch einen Aktivitätswert mit denen des Bindungsbezuggswertes gemeinsam hat (2).

\section{Ergebnisse}

Tabelle 1 zeigt, dạ bei geringerer Antikörperkonzentration und längerer Inkubationszeit mit allen Methoden niedrigere Werte für die untere Nachweisgrenze erhalten werden. Die Ergebnisse zeigen eine beträchtliche Variation, wobei die Werte der Methode nach Markowetz \& Munz auf 6,3 und 3,1 $\mu \mathrm{g} / 1$ beschränkt sind. Im Fallè der unteren Nachweisgrenze von $3,1 \mu \mathrm{g} / \mathrm{l}\left(\mathrm{D}^{*}\right)$ wird - im Gegensatz zu den Versuchen $C$ und $D$ - ein linearer Bereich von $1,6-6,3 \mu \mathrm{g} / \mathrm{l}$ gefunden. Der mittlere Bindungswert $(\% \overline{\mathrm{B}}$, Markowetz \& Munz) ist verhältnismäßig

Tab. 1. Methodik und untere Nachweisgrenze.

\%B: Prozentuale gebundene Aktivität

$\% \overline{\mathrm{B}}$ : Mittlere prozentuale gebundene Aktivität

h: Stunden

n: Anzahl der Meßwerte

VK: Variationskoeffizient

Bestimmungsmethoden für die untere Nachweisgrenze s. Methodik

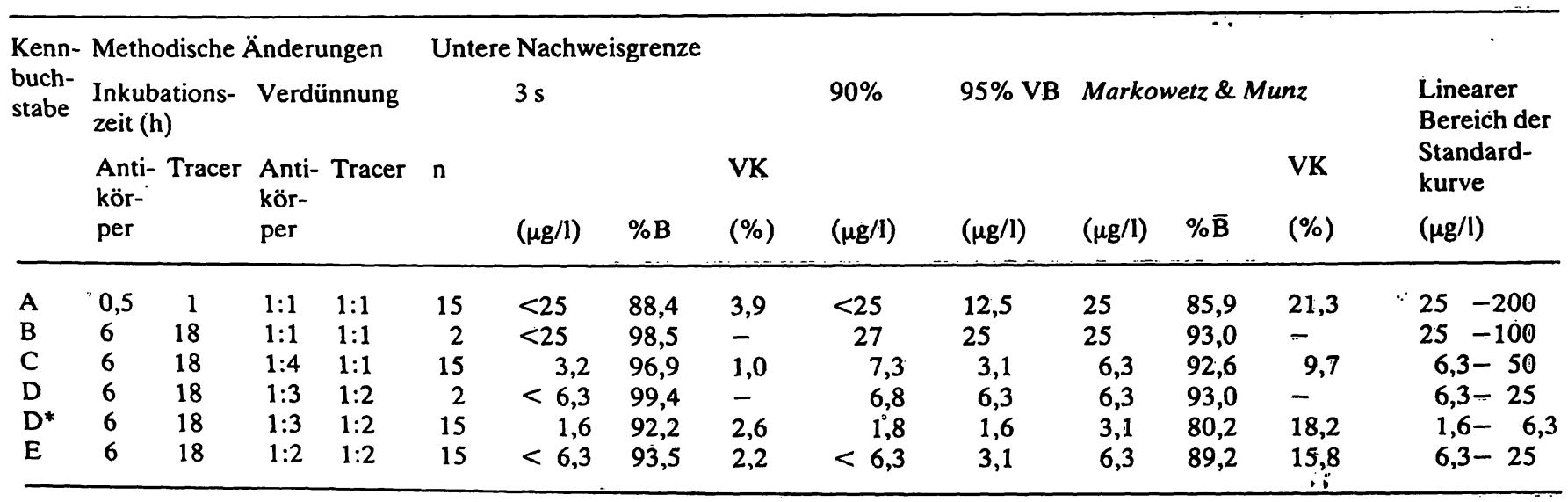


(C, D) stark erniedrigt. Der 3 s-Methoden-Bindungswert (\%B) ist in Richtung 90\%-Bindung verschoben $(C, D)$. Alle diese Veränderungen lassen sich durch eine Erhöhung der Antikörperkonzentration (E) wieder umkehren. Nimmt man den Versuch $D^{*}$ bei der Messung der unteren Nachweisgrenze aus, dann ergibt sich die untere Nachweisgrenze nach Markowetz \& Munz zu 6,3 $\mu \mathrm{g} /$.

Bei Mehrfachmessung $(n=15)$ korreliert der Variationskoeffizient (VK), der sich bei der Konzentration der unteren Nachweisgrenze nach Markowetz \& Munz berechnen läßt, gut sowohl mit dem 3 s-Methoden-Bindungswert $(r=0,98)$ als auch mit dem VK $(r=0,98)$, der sich mit der entsprechenden Aktivität bei der $3 \mathrm{~s}$-Methode berechnen läßt.

Ein 10jähriges Mädchen entwickelte nach hyperosmolarem diabetischen Koma mit zweitägiger Bewußtlosigkeit eine akute Rhabdomyolyse mit myoglobinurischem Nierenversagen, das durch Dialysebehandlung überbrückt wurde (3). Tabelle 2 zeigt den Myoglobinkonzentrationsverlauf im Urin. Die anfangs außerordentlich hohe Konzentration fällt auf Werte unterhalb der unteren Nachweisgrenze nach Markowetz \& Munz ab. Die entsprechenden Kreatininwerte im Serum zeigen eine Normalisierung der Nierenfunktion an.

Tab. 2. Myoglobin- und Kreatininkonzentration im Urin bzw. Serum bei einem 10jährigen Mädchen mit myoglobinurischem Nierenversagen.

\begin{tabular}{rcc}
\hline Datum & $\begin{array}{l}\text { Myoglobin } \\
(\mu \mathrm{g} / \mathrm{l})\end{array}$ & $\begin{array}{l}\text { Kreatinin } \\
(\mathrm{mg} / \mathrm{l})\end{array}$ \\
\hline 8.1 .82 & 26452 & 86 \\
20.1 .82 & 3369 & 49 \\
26.1 .82 & 21 & 13 \\
3.2 .82 & $<6,3$ & 7 \\
4.2 .82 & $<6,3$ & 5 \\
8.2 .82 & $<6,3$ & 5 \\
\hline
\end{tabular}

\section{Diskussion}

Die Konfusion, die im Zusàmmenhang mit dem Problem „Sensitivität beim Radioimmunoassay“ vorherrschte, veranlaßte Ekin (4), die Sensitivität über die untere Nachweisgrenze zu definieren ${ }^{1}$ ), wobei die untere Nachweisgrenze (UNG) als Funktion der Präzision (UNG $=\mathrm{f}($ Präzision)) und der Steigung

1) $\mathrm{UNG}=\Delta \mathrm{P}_{\mathrm{L}}=0 /$ Steigung der Standardkurve bei $\mathrm{L}=0$; $\Delta P_{L}=0$ : Fehler der Messung eines Parameters $P$ bei der Ligandenkonzentration $\mathrm{L}=0$. beschrieben wird. Wenngleich sich inzwischen wohl eine einheitliche Meinung gebildet hat, da $B$ die der Sensitivität korrespondierende Meßgröße die untere Nachweisgrenze ist, so konnte sich das der Ekinschen Definition folgende Meßverfahren für die untere Nachweisgrenze, möglicherweise aufgrund der im folgenden dargestellten Einwände, nicht durchsetzen.

In der Theorie sollte - wie in vielen Fällen bei der Auftragung der prozentualen gebundenen Aktivität eines RIA gegen die Konzentration ersichtlich - die Steigung der Standardkurve bei $\mathrm{L}=0$ auch 0 sein. In diesem Fall ist die untere Nachweisgrenze nach Ekin aber nicht definiert. Darüber hinaus ist zu fragen, ob die Ekinsche Definition die Funktion UNG $=\mathrm{f}($ Präzision) ausreichend beschreibt. Da die Präzision im Bereich geringer Ligandenkonzentration abnimmt und die Steigung von der Präzision der Messung aller Ligandenkonzentrationen $>0$ abhängt, wobei der Zusammenhang zwischen Steigung und Präzision nicht bekannt ist, ist zu fragen, ob dieser Bereich geringer Ligandenkonzentration nicht unmittelbarer als durch die Steigung in die Bestimmung der unteren Nachweisgrenze eingehen sollte. Úberdies besteht noch die Schwierigkeit, die zur Ermittlung der Steigung notwendigen Berechnungsgrundlagen sowohl für die mathematische Beschreibung der verschiedenen Standardkurvenformen beim RIA als auch für die dazu notwendigen statistischen Kriterien verbindlich $\mathrm{zu}$ definieren.

Somit ist wohl verständlich, daß verschiedene Verfahren zur Sensitivitätsbestimmung in der Literatur $(5,6,7)$ beschrieben sind. Es ist jedoch immer noch nicht entschieden, welchem Verfahren der Vorzug zu geben ist.

Den vorliegenden Ergebnissen zufolge besteht zwischen den verwendeten Bestimmungsverfahren für die untere Nachweisgrenze kein grundsätzlicher Unterschied, da mit Änderung der Methodik in jedem Fall niedrigere Werte für die untere Nachweisgrenze erhalten werden (s. Tab. 1). Dies läßt sich darauf zurückführen, daß mit allen Methoden die Präzision des Testes im niedrigen Konzentrationsbereich gemessen wird und nach Ekin UNG $=\mathrm{f}($ Präzision) ist. Wenngleich keine grundsätzlichen Unterschiede bestehen, so sind dennoch Differenzen zwischen den einzelnen Verfahren vorhanden, die insbesondere auf der Unterscheidung der „Präzision in der Serie“ von der „Präzision von Tag zu Tag“ basieren. Während nämlich $90 \%$ - und 3 s-Methode jeweils nur einen Punkt der Standardkurve als untere Nachweisgrenze definieren, beruht die Bestimmung der unteren Nachweisgrenze mittels der Methode nach Mar- 
kowetz \& Munz und der 95\% VB-Methode auf der Abgrenzung von Bereichen, d.h. nichts anderes, als $\mathrm{da}$ die Resultate der beiden zuerst genannten Verfahren ein Ergebnis einer „Präzision von Tag zu Tag"-Bestimmung liefern, während die beiden letzteren Verfahren eine „Präzision in der Serie“-Bestimmung darstellen.

Die Unterscheidung der Verfahren nach der Art der Präzisionsmessung erlaubt nun auch eine Aussage über die zu verwendende Bestimmungsmethode für die untere Nachweisgrenze: Der Methode nach Markowetz \& Munz als einem „Präzision in der Serie“Bestimmungsverfahren ist dabei der Vorzug zu geben, da dieses Verfahren es erlaubt, die untere Nachweisgrenze in einem Versuchsansatz zu bestimmen. Offensichtlich ist der von Markowetz \& Munz gewählte Bereich groß genug, um Präzisionsveränderungen ohne Änderungen der unteren Nachweisgrenze zuzulassen. Die nach Markowetz \& Munz bestimmte untere Nachweisgrenze von $6,3 \mu \mathrm{g} / 1$ für den Meßbereich 6,3 bis $50 \mu \mathrm{g} / \mathrm{l}$ wurde somit zur Abgrenzung pathologischer Myoglobinkonzentrationen im Urin verwendet. $\mathrm{Da} B$ diese untere Nachweisgrenze den praktischen Belangen entspricht, zeigen Myoglobinkonzentrationswerte kleiner als die untere Nachweisgrenze an, die bei einem Kind mit myoglobinurischem Nierenversagen in Ubereinstimmung mit den entsprechenden Kreatininwerten bei Normalisierung der Nierenfunktion beobachtet werden (s. Tab. 2).

Die Vorteile des Verfahrens von Markowetz \& Munz gegenüber den anderen Methoden sind nicht auf eine einmalige Bestimmung der unteren Nachweisgrenze beschränkt. Vielmehr lassen sich auch die Ergebnisse der einzelnen Methoden mit Hilfe der Resultate des Verfahrens nach Markowetz \& Munz in Beziehung zueinander setzen, da der Variationskoeffizient (VK), der bei der Bestimmung der unteren Nachweisgrenze nach Markowetz \& Munz berechnet werden kann, sowohl mit dem 3 s-Bindungswert $(\% \mathrm{~B})$ als auch mit dem entsprechenden

\section{Literatur}

1. Kreuzfelder, E. \& Kuwert, E. (1982) Lab. Med. 6, A+B 97103.

2. Markowetz, D. \& Munz, E. (1981) Kritische Betrachtung der Definition der unteren Nachweisgrenze bei verschiedenen diagnostischen Methoden (RIA, EIA, Enzymbestimmung, Substratbestimmung). Vortrag beim Kongre $B$ der Deutschen Gesellschaft für Laboratoriumsmedizin e. V., Berlin, 3. 5. - 7. 5 . 1981.

3. Pistor, K., Graben, N., Kreuzfelder, E. \& Bartholomé, W. (1983) Int. J. Ped. Nephrol. (im Druck).

4. Ekin, R. P. (1970) Theoretical aspects of saturation analysis In: In vitro procedures with radioisotopes in medicine. IAEA. Wien, S. $325-353$.
VK der 3 s-Methode korreliert. Es läßt sich so z.B. verstehen, daß die $90 \%$-Methode als Bestimmungsverfahren für die untere Nachweisgrenze brauchbar ist. Setzt man nämlich \%B $=90$ in die entsprechende Regressionsgeradengleichung ein, so erhält man VK $=20 \%$; ein Wert, der sicherlich nicht nur bei diesem RIA berechnet werden kann. Úberdies könnte dieses Verfahren genutzt werden, die Beziehung zwischen Präzision, unterer Nachweisgrenze und Steigung zu untersuchen: Die VK's der Ligandenkonzentrationen 0 und untere Nachweisgrenze korrelieren miteinander. Ein weiterer Vorteil dieses Verfahrens ist, daß es ebenso zur Bestimmung der oberen Nachweisgrenże geeignet ist. Am Rande sei angemerkt, daß das Verfahren nach Markowetz \& Munz mit einem minimalen mathematischen Aufwand angewandt werden kann.

Es wurde bisher lediglich die Bedeutung der Präzisionsmessung für die Bestimmung der unteren Nachweisgrenze herausgestellt. Neben der Präzision beeinflussen allerdings auch noch andere Kenngrößen die untere Nachweisgrenze. So wird in dieser Arbeit z.B. gezeigt, daß eine Veränderung der Antikörperbindungseigenschaft und/oder der Antikörperkonzentration zur Verschiebung des Meßbereiches in Richtung niedrigerer Konzentration führt. In diesem Fall läßt sich auch eine niedrigere untere Nachweisgrenze in der Definition nach Markowetz \& Munz beobachten.

Der vorliegenden Arbeit zufolge, ist das Verfahren nach Markowetz \& Munz sowohl aus theoretischer als auch aus praktischer Sicht am besten geeignet, die Sensitivität als untere Nachweisgrenze zu bestimmen. Es bleibt allerdings abzuwarten, inwieweit sich diese Aussage verallgemeinern läßt.

\section{Danksagung}

Der Firma Isotopen Diagnostik CIS, Dreieich, danken wir für das freundliche Entgegenkommen. Herrn J: Czech danken wir für die hervorragende technische Assistenz.
5. Chard, T. (1978) An introduction to radioimmunoassay and related techniques. In: Laboratory techniques in biochemistry and molecular biology. Work, T. S. \& Work, E. North Holland Publishing Company. Amsterdam-New York-Oxford.

6. Sokolowski, G. \& Wood, W. G. (1981) Radioimmunoassay in Theorie und Praxis. Schnetztor Verlag, Konstanz.

7. Rodbard, D., Rayford, P. L., Cooper, J. A. \& Ross, G. T. (1969) J. Clin. Endocrinol. Metabolism 28, 1412-1418.

Dr. rer. nat. Ernst Kreuzfelder Dipl. Biochem. Institut fựr medizinische Virologie und Immunologie Universitätsklinikum Essen

Hufelandstraße 55

D-4300 Essen 1 


\title{
Excessive Consumption of Alcohol in Men as a Biological Influence Factor in Clinical Laboratory Investigations ${ }^{1}$ )
}

\author{
By D. Stamm, E. Hansert and W. Feuerlein \\ Max Planck Institute for Psychiatry, Munich
}

(Received December 27, 1982/October 3, 1983)

Summary: It is known that excessive alcohol consumption leads to changes in clinical chemical and haematological parameters that are reversed to a greater or lesser degree after alcohol consumption ceases. Such factors that lead to changes in vivo in the parameters studied are termed biological influence factors. In the study reported here the biological influence factor "excessive alcohol consumption" was assessed in its most severe form, namely alcoholism.

To this end 24 clinical chemical parameters and 8 haematological parameters were studied in 82 male alcoholics.

The diagnoses of alcohol abuse and alcoholism were made on the basis of the Munich Alcoholism Test (MALT) and the information obtained in the following standardized interviews and examinations: past history, an alcohol questionnaire, general physical examination and neurological examination. All forms were filled in completely.

All steps in the clinical laboratory investigations were standardized, and all were subject to ongoing reliability control. In the comparison of the analytical results for the alcoholics with reference intervals for healthy persons (normal ranges) the following alterations were found, the percentage of the alcoholics being given in parentheses.

Increase, i.e. result above the upper limit of the reference interval:

$\gamma$-Glutamyltransferase

Aspartate aminotransferase

Creatine kinase

$(69 \%)$

Mean corpuscular volüme
$\gamma$-Globulins

Bilirubin, total

Uric acid

Serum iron

Cholesterol

Triglycerides

Decrease, i.e. result below the lower limit of the reference interval:

$\begin{array}{lc}\text { Cholinesteràse } & (10 \%) \\ \text { Sodium } & (8.5 \%) \\ \text { Potassium } & (17 \%) \\ \text { Chloride } & (10 \%) \\ \text { Phosphorus, inorg. } & (8 \%) \\ \text { Haemoglobin } & (28 \%) \\ \text { Haematocrit } & (11 \%)\end{array}$

Magnesium

Serum iron

Cholesterol

1) This research project was partially supported by funds provided by the Bayerisches Staatsministerium für Arbeit und Sozialordnung (Bavarian State Ministry of Labour and Welfare). 
Furthermore, the result was below the location parameter of the reference sample group for:

Urea

Thus excessive alcohol consumption is clearly a biological influence factor that must be taken into consideration in the medical assessment of analytical results for numerous clinical chemical and haematological parameters.

In determining reference values and reference intervals for the transverse assessment of analytical results for these parameters it is therefore absolutely essential that subjects with excessive alcohol consumption be excluded from the reference sample group.

According to the present data, alcoholism can be neither detected nor excluded by evaluating a single parameter, i.e. on the basis of only one clinical chemical finding.

Der übermäßige Alkoholkonsum von Männern als Einflußgröße bei klinisch-chemischen Untersuchungen

Zusammenfassung: Der übermäßige Alkoholkonsum führt bekanntlich zu Veränderungen klinisch-chemischer und hämatologischer Kenngrößen, die sich nach Alkoholentzug in unterschiedlichem Grade wieder zurückbilden. Solche Einflüsse, die in vivo zu Veränderungen der untersuchten Kenngrößen führen, werden als Einflußgrößen bezeichnet. In der vorliegenden Arbeit wird die Einflußgröße übermäßigigen Alkoholkonsums in seiner ausgeprägtesten Form, dem Alkoholismus, studiert:

Dazu wurden bei 82 Patienten (Männer) mit sicher diagnostiziertem Alkoholabusus und Alkoholismus gleichzeitig 24 klinisch-chemische Kenngrößen und 8 hämatologische Kenngrößen untersucht.

Die Diagnose des Alkoholabusus und Alkoholismus erfolgte aufgrund des Münchner Alkoholismustests (MALT) sowie folgenden standardisierten vollständigen Erhebungen oder Untersuchungen: Anamnese, Alkoholerhebungsbogen, internistische Untersuchung und neurologische Untersuchung.

Alle Teilschritte der klinisch-chemischen Untersuchungen waren standardisiert und unterlagen einer ständigen Zuverlässigkeitskontrolle. Bei dem Vergleich der Analysenergebnisse von den Alkoholikern mit den Referenzintervallen für Gesunde (Normalbereiche) wurden folgende Veränderungen gefunden, wobei die Prozentsätze jeweils in Klammern angegeben sind.

Erhöhungen, oberhalb der Obergrenze des Referenzintervalls

$\gamma$-Glutamyltransferase

Aspartat-aminotransferase

Alanin-aminotransferase

Alkalische Phosphatase

Glutamat-dehydrogenase

Kreatin-kinase

Erythrocytenvolumen (MCV)
$\gamma$-Globuline

Bilirubin, gesamt

Harnsäure

Serum-Eisen

Cholesterin

Triglyceride

Erniedrigungen, unterhalb der Untergrenze des Referenzintervalls

$\begin{array}{lc}\text { Cholinesterase } & (10 \%) \\ \text { Natrium } & (8,5 \%) \\ \text { Kalium } & (17 \%) \\ \text { Chlorid } & (10 \%) \\ \text { Phosphor, anorg. } & (8 \%) \\ \text { Hämoglobin } & (28 \%) \\ \text { Hämatokrit } & (11 \%)\end{array}$

Magnesium ..

Serum-Eisen

Cholesterin

Unterhalb des Lagekriteriums der Reference sample group lagen außerdem:

Harnstoff

$(80 \%)$.

Danach ist der übermäßige Alkoholkonsum eine Einflußgröße, die bei der medizinischen Beurteilung der Analysenergebnisse vieler klinisch-chemischer und hämatologischer Kenngrößen berücksichtigt werden muß. 
Bei der Ermittlung von Referenzwerten und Referenzintervallen zur transversalen Beurteilung von Analysenergebnissen dieser Kenngrößen müssen Probanden mit einem übermäßigen Alkoholkonsum infolgedessen unbedingt ausgeschlossen werden.

Die Erkennung und der Ausschluß des Alkoholismus können nach den vorliegenden Daten nicht durch die Beurteilung einer einzigen Kenngröße, also aufgrund eines klinisch-chemischen Befundes, erfolgen.

\section{Introduction}

It is well known that excessive consumption of alcohol leads to changes in clinical chemical parameters and that these changes are reversed to differing degrees when drinking ceases. Altered values have been reported most frequently for $\gamma$-glutamyltransferase and mean corpuscular volume (MCV) (1-4).

Factors such as this that lead to changes in vivo in one or more parameters are referred to as biological influence factors (5); they always have a relationship to the patient. Their influence is independent of the analytical specificity of the analytical method used, and therefore they cannot be eliminated by switching to a more specific method.

These biological influence factors must be taken into account in the medical assessment of an analytical result for the purpose of producing a meaningful clinical laboratory finding (6).

The problem of the role of the biological influence factor "excessive alcohol consumption" has not been dealt with adequately, i.e. in systematic studies of clinical chemical parameters in which patients whose alcohol intake is excessive are studied under carefully defined and controlled conditions and in which there is a completely independent outside criterion.

The subjects selected for the present study were patients who clearly consumed excessive amounts of alcohol and whose excessive drinking had led to a disturbance of physical, mental and/or social function. This corresponds to the 1952 definition of alcoholism by the World Health Organization and the term "alcohol-related disabilities" used by Edwards et al. (7). These subjects are hereafter referred to as alcoholics. It is intentional that the development of alcohol dependence is not discussed in this paper.

Since 1977 there has been a reliable "combination" test for the detection of alcoholism $(8,9)$, the $\mathrm{Mu}$ nich Alcoholism Test (MALT). This test consists of two parts, the first requiring a self-rating by the patient (part S) and the second an assessment by a physician (part F) after a thorough examination of the patient. The two parts of the test must be evaluated together. Part F contains one clinical chemistry cri- terion (the result for at least one of the parameters aspartate aminotransferase, alanine aminotransferase and $\gamma$-glutamyltransferase must be outside the normal range). For methodological reasons this criterion was omitted when the data in part $F$ were evaluated for use in the present study.

Changes in a great many clinical chemical parameters have been observed in connection with alcoholism (tab. 0-1). As already mentioned, the most frequently observed changes (25) are elevations in $\gamma$ glutamyltransferase, the aminotransferases and mean corpuscular volume (MCV). However, these changes are also found in connection with many other disorders and as side effects $(26,18)$ of drugs (biological influence factors). Unfortunately, in most of the past publications on changes in these parameters the outside criterion for alcoholism is not stated clearly and there is no information on the patients' past history and no mention of any general physical, neurological or psychiatric assessment. In other reports the information on the clinical laboratory investigations is so brief that no comparisons are possible.

\section{Purpose of the Study and Experimental Design}

The present study was designed to investigate the biological influence factor "excessive alcohol consumption" in its extreme form, referred to here as alcoholism, with regard to its effects on the results of investigations that are part of the routine program of a clinical chemistry laboratory. To this end a comparison of analytical results for alcoholics and for healthy persons was planned. The objective was to provide answers to the following questions:

1. For which parameters are more than $10 \%$ of the analytical results for the alcoholics outside the reference interval for healthy persons?

2. For which other parameters is the distribution of the analytical results for the alcoholics within the reference interval different from that for the reference sample group of healthy persons? 
Tab. 0-1. Changes in the concentration of clinical chemical parameters in alcoholics (with references).

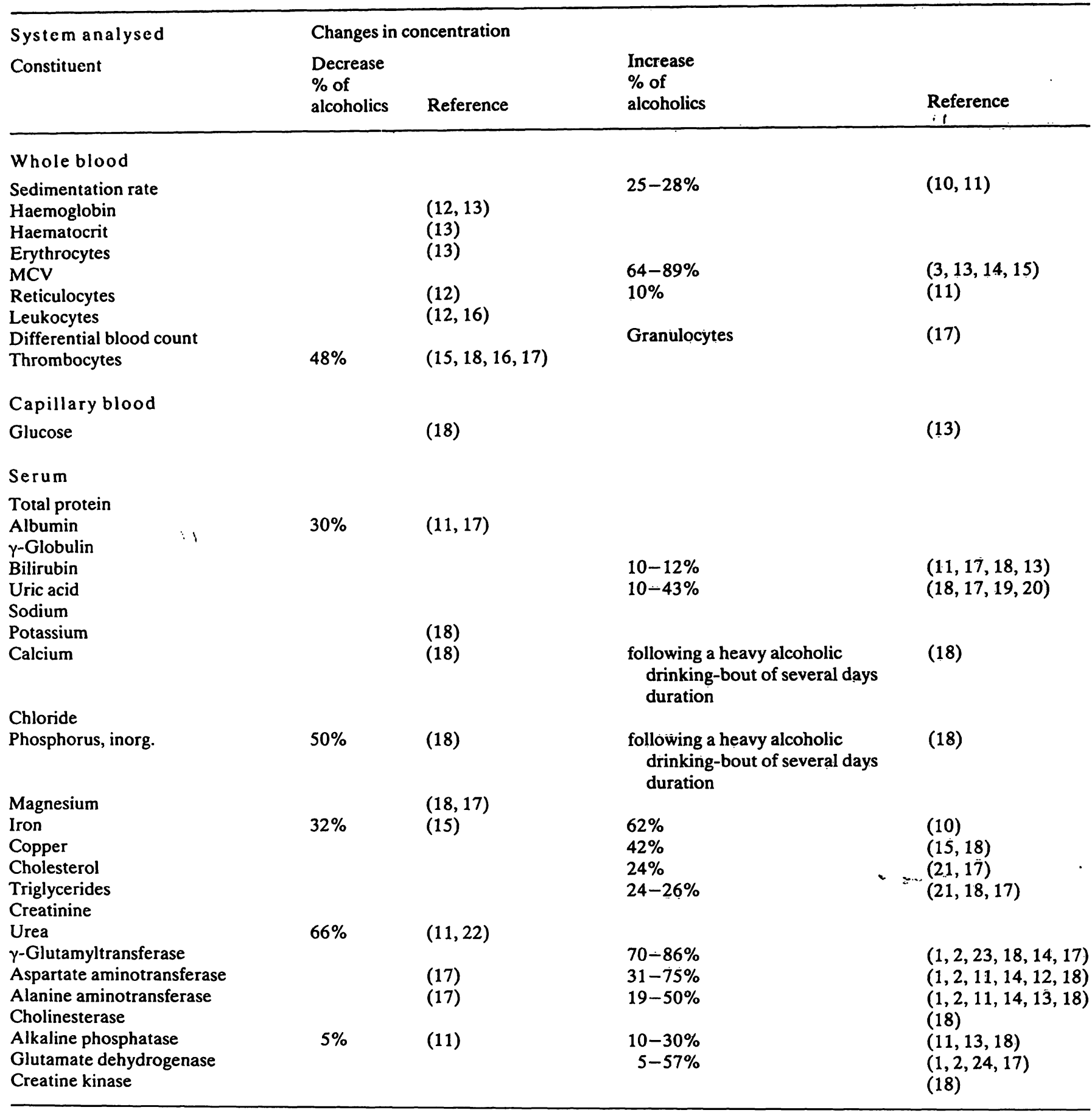

3. Does the biological influence factor "excessive alcohol consumption" have statistically significant effects which are of such medical importance that this factor must be taken into account expressly in the selection of a reference sample group of healthy persons?

4. For which parameters can alcoholics be left in a reference sample group used in the determination of reference intervals and when must they be excluded?

5. For which parameters must the biological influence factor "excessive alcohol consumption" always be taken into consideration in the medical assessment of analytical results?

\subsection{Subjects}

Since for ethical reasons it was not possible to subject "healthy" persons to excessive amounts of alcohol for long periods of time, the alcoholics who served as subjects in this study were selected from the patient population of several hospitals. The questions raised above can be answered with sufficient reliability only if the study is based on alcoholics who have been carefully examined and thus for whom the diagnosis of alcoholism is definite. Moreover, for the purposes of such a study the alcoholics must be diagnosed on the basis of an examination scheme that can serve as an outside criterion, and for this reason the schéme may not include 
any clinical chemical parameters. In the present study the MALT was used to diagnose alcoholism, its single clinical chemistry criterion (part F, item 1) being omitted to ensure that the validity of the instrument was not affected (see above).

The reference intervals and location parameters for the reference values used for the "healthy" subjects were obtained with the methods we commonly use, and they were either determined by us or taken from the literature and checked by us.

In this connection we were also interested in the question of whether for certain parameters the effect of alcoholism is so great that alcoholics can be distinguished clearly from other patients in a hospital population on the basis of the resulting alterations. Therefore a group of subjects was included whose members had a disorder of some kind but who were definitely not alcoholics and who belonged to the same clinical population as the known alcoholics. For this reason both the alcoholic and the non-alcoholic patients were selected from the patients at a general city hospital (Munich-Schwabing City Hospital), a psychiatric hospital (Haar Regional Hospital) and (alcoholics only) a hospital for alcoholics (Annabrunn Alcoholism Treatment Centre) (tab. 1-1).

There were no significant differences in the age distributions of the alcoholics and non-alcoholics (tab. 1-2).

The physical and mental disorders of the alcoholics and the nonalcoholics are shown in table 1-3. The mental disorders were classified according to the International Classification of Diseases (ICD, 8th revision). The patients were selected for this study on the basis of the MALT immediately following admission. Only at Munich-Schwabing City Hospital was it possible to obtain equal numbers of alcoholics and non-alcoholics from the same patient population. Since, on admission, diagnoses other than alcoholism were usually either unknown or had not yet been confirmed they could not be used as a criterion for subject selection. This is the

Tab. 1-1. Patients studied (exclusively men).

\begin{tabular}{lll}
\hline Hospital & Alcoholics & Non-alcoholics \\
\hline $\begin{array}{l}\text { Munich-Schwabing } \\
\text { City Hospital }\end{array}$ & 27 & 30 \\
$\begin{array}{l}\text { Haar Regional Hospital } \\
\text { Annabrunn Alcoholism }\end{array}$ & 20 & 40 \\
$\begin{array}{l}\text { Treatment Centre } \\
\Sigma\end{array}$ & 35 & - \\
\hline
\end{tabular}

Tab. 1-2. Age distribution of the patients.

\begin{tabular}{lcc}
\hline $\begin{array}{l}\text { Age }^{\mathrm{a}} \\
\text { (a) }\end{array}$ & $\begin{array}{l}\text { Alcoholics } \\
\mathrm{N}(\%)\end{array}$ & $\begin{array}{l}\text { Non-alcoholics } \\
\mathrm{N}(\%)\end{array}$ \\
\hline $20-25$ & $5(6.1)$ & $6 .(8.6)$ \\
$26-30$ & $9(11.0)$ & $5(7.1)$ \\
$31-35$ & $9(11.0)$ & $12(17.1)$ \\
$36-40$ & $17(20.7)$ & $14(20.0)$ \\
$41-45$ & $16(19.5)$ & $12(17.1)$ \\
$46-50$ & $17(20.7)$ & $13(18.6)$ \\
$51-5.5$ & $7(8.5)$ & $4(5.7)$ \\
$>55$ & $2(2.4)$ & $4(5.7)$ \\
\hline
\end{tabular}

\section{${ }^{a}$ Mean age}

(a)

$\overline{\mathbf{x}} \pm \mathbf{s}$

$40.5 \pm 9.2$ explanation for the different kinds of disorders in the two patient groups. In the validation study now in progress alcoholics and non-alcoholics with known disorders (readmissions) are being compared.

\subsection{Clinical laboratory parameters studied}

Those clinical chemical parameters were selected for study for which differences have been reported between the values for alcoholics and the normal ranges for healthy persons. In addition, the parameters had to be part of the routine programme of a clinical chemistry laboratory. Table $0-1$ gives a partial list of relevant literature from the past 10 years, some of the reports being contradictory. For the sake of brevity, preference was given to review articles.

\section{Methods}

\subsection{Patient selection}

The patients who had been selected for participation in the study were given an information sheet on the purpose of the study, what would be expected of them and the precautions that would be taken to preserve anonymity. They were asked to indicate their willingness to participate by signing the information sheet.

Only those patients were included whose primary illness would permit a coherent conversation about somatic complaints and about drinking habits (alcohol). Excluded from the study were patients who were obviously misusing drugs, those with diagnosed tumours and those with physical infirmities that would have prohibited a neurological assessment of walking and standing performance.

Tab. 1-3. Disorders found in the two groups of patients (more than one possible).

\begin{tabular}{lcc}
\hline Kind of disorder/organ & Alcoholics & Non-alcoholics \\
\hline No other physical disorder & 29 & - \\
Liver & 41 & 1 \\
Pancreas & 1 & 1 \\
Gastrointestinal tract & 4 & 7 \\
Blood and haematopoietic tissues & 1 & - \\
Neurological disorders & 4 & 3 \\
Mental disorders: & & \\
$\quad$ Alcohol delirium & 3 & - \\
Schizophrenia & - & 27 \\
$\quad$ Affective psychoses & - & 1 \\
$\quad$ Neuroses & - & 2 \\
Personality disorders & - & 3 \\
Suicide attempt & - & 3 \\
Chronic brain syndrome & 1 & - \\
$\quad$ Adjustment reaction & - & 3 \\
Mineral metabolism & - & - \\
Metabolic disorders & 9 & 7 \\
Endocrine disorders & - & 2 \\
Drug abuse & 4 & - \\
Kidneys & - & 4 \\
Orthopaedic disorders & 1 & 4 \\
Skin & 5 & - \\
Respiratory system & 2 & 2 \\
Traumas & 1 & 1 \\
N = & 82 & 70 \\
\hline & & \\
\hline
\end{tabular}




\subsubsection{Criteria for selection of the alcoholics}

The patients in this group were known alcoholics who had last consumed alcohol within the previous 7 days. They also had to have indicated a willingness to undergo treatment so that they could be expected to stay at the hospital for more than 14 days. This was to ensure that at the end of a two-week period further specimens could be collected for assessment. A report on the follow-up studies including comparisons with the initial data has been published elsewhere (27).

\subsubsection{Criteria for selection of the non-alcoholics}

Those patients who agreed to consider participating in the project were selected from the same wards at the Schwabing and Haar hospitals as the alcoholics so that both groups of subjects would be from the same population. Patients were then excluded if they were taking anticonvulsant drugs or if they had more than 5 points on part $S$ of the MALT $(8,9)$.

\subsection{Examination of the patients}

Each patient was interviewed and examined by a physician, for the alcoholics the emphasis being on problems related to alcoholism and for the non-alcoholics on the disorder(s) of the particular patient. All of the information shown in table 2-1 was obtained for each patient, being recorded on the different forms in a manner suitable for easy data processing. All interviews and examinations of a given patient (except laboratory analysis) were performed by the same physician, and all information was recorded on the special forms regularly used at the Max-Planck-Institut für Psychiatrie.

Tab. 2-1. Information obtained on each patient.

1. MALT (Munich Alcoholism Test)

Self-rating (part S)

Physician's assessment (part F)

2. Past history

3. Alcohol questionnaire

(Max-Planck-Institut für Psychiatrie)

4. Physical examination

5. Neurological examination

6. Laboratory tests
The form for the patient's past history has 42 questions, which are answered by marking the appropriate box. The extensive questionnaire on alcohol consists of 57 questions on the onset and frequency of alcohol abuse, amount of alcohol consumed, drinking habits, alcohol-related complaints and previous treatment for alcoholism. The findings from the thorough physical and neurological examinations are recorded directly on standardized forms.

All of the above information was obtained for each patient included in the study.

2.3 Clinical chemical parameters studied, analytical methods used and reliability criteria

\subsubsection{Analytical methods}

Those parameters for which changes have been reported in alcoholics (tab. 0-1) were studied in all patients included in this pro- ject. Tables 2-2, 2-3 and 2-4 show the investigations carried out, arranged according to system, including the analytical principle and a reference for the method used. In addition, the qualitative tests shown in table 2-5 were also performed.

Tab. 2-5. Qualitative clinical laboratory investigations.

Urine (morning specimen)

Protein

Glucose

Acetone and acetoacetic acid

Sediment

Feces

Blood via Haemoccult test

\subsubsection{Reliability criteria}

All quantitative clinical laboratory methods were subject to internal quality control with a control specimen system $(52-55)$. The results of day-to-day precision control at the most frequent decision limits are shown in table 2-6. Accuracy control was carried out on an ongoing basis using control specimens with assigned values determined in high-quality laboratories that were independent of the manufacturers of the specimens, the determinations being made in accordance with the Guidelines of the Medical Society of West Germany (56). In some of these control specimens the concentrations were in the normal range, in others in

Tab. 2-2. Haematological studies on venous blood (blood collected with EDTA).

\begin{tabular}{llrl}
\hline Constituent & Analytical principle & Reference \\
\hline Haemoglobin & Haemiglobin cyanide method & $(28)$ & $(29)$ \\
Haematocrit & Microhaematocrit with haematocrit centrifuge & $\ldots$ & $(29)$ \\
Erythrocytes & Chamber count & $(29)$ \\
MCV & Calculated from haematocrit and erythrocyte count & $(29)$ \\
Reticulocytes & Reticulocyte count on blood film & \\
Leukocytes & Chamber count & \\
Differential blood count & Stained blood film examination & \\
Thrombocytes & Chamber count after dilution with Plaxan & \\
\hline
\end{tabular}

Tab. 2-3. Clinical laboratory investigation on capillary blood.

\begin{tabular}{llr}
\hline Constituent & Analytical principle & Reference \\
\hline Glucose & Hexokinase glucose-6-phosphate dehydrogenase reaction & $(30)$ \\
\hline
\end{tabular}


Tab. 2-4. Clinical laboratory investigations on serum.

\begin{tabular}{|c|c|c|}
\hline Constituent & Analytical principle & Reference \\
\hline $\begin{array}{l}\text { Total protein } \\
\text { Electrophoresis } \\
\text { - Albumin } \\
-\gamma \text {-Globulins } \\
\text { Bilirubin } \\
\text { Uric acid } \\
\text { Sodium, potassium, calcium } \\
\text { Chloride } \\
\text { Phosphorus, inorg. } \\
\text { Magnesium } \\
\text { Serum iron } \\
\text { Serum copper } \\
\text { Cholesterol } \\
\text { Triglycerides } \\
\text { Creatinine } \\
\text { Urea } \\
\gamma \text {-Glutamyltransferase } \\
\text { Aspartate aminotransferase } \\
\text { Alanine aminotransferase } \\
\text { Cholinesterase } \\
\text { Alkaline phosphatase } \\
\text { Glutamate dehydrogenase } \\
\text { Creatine kinase }\end{array}$ & $\begin{array}{l}\text { Photometry of the azopigment } \\
\text { Destruction of uric acid by uricase with Kageyama reaction } \\
\text { Emission flame photometry with Li-guideline, Eppendorf flame photometer } \\
\text { Coulometry } \\
\text { Reduction of phosphomolybdate to molybdenum blue } \\
\text { Atomic absorption spectrophotometry } \\
\text { Bathophenanthroline after precipitation of protein } \\
\text { Bathocuproine after precipitation of protein } \\
\text { Liebermann-Burchard reaction, Watson modification } \\
\text { Enzymatic determination of glycerol after saponification with KOH } \\
\text { Jaffe reaction after adsorption on fuller's earth with precipitation of protein } \\
\text { Destruction of urea by urease with Berthelot reaction } \\
\text { Continuous determination with } \gamma \text {-glutamyl-3-carboxy-4-nitranilide } \\
\text { Standard method of the German Society for Clinical Chemistry } \\
\text { Standard method of the German Society for Clinical Chemistry } \\
\text { Continuous measurement with S-butyryl-thiocholine-iodide } \\
\text { Standard method of the German Society for Clinical Chemistry } \\
\text { Standard method of the German Society for Clinical Chemistry } \\
\text { N-acetyl cysteine activated, standard method of the German Society for Clinical Chemistry }\end{array}$ & $\begin{array}{l}(36) \\
(37) \\
(38) \\
(39) \\
(40) \\
(41) \\
(42) \\
(43) \\
(44,45) \\
(44,45) \\
(48,49,51) \\
(44,45) \\
(46) \\
(46)\end{array}$ \\
\hline
\end{tabular}

Tab. 2-6. Between-day precision.

\begin{tabular}{|c|c|c|c|c|c|}
\hline \multicolumn{6}{|l|}{ System analysed } \\
\hline Constituent & (Unit) & Precision control specimen & $\overline{\mathbf{x}}$ & $\mathbf{s T}_{\mathbf{T}}$ & $\begin{array}{l}\text { CV } \\
(\%)\end{array}$ \\
\hline \multicolumn{6}{|l|}{ Whole blood } \\
\hline Haemoglobin & $(g / 1)$ & RK: Merz + Dade CH 60 Normal & 1.48 & 0.026 & 1.76 \\
\hline Haematocrit & (1) & Hematology control normal CH 60 Lab. 530; Merz + Dade & 0.35 & 0.01 & 2.9 \\
\hline Erythrocytes & $\left(\times 10^{12} / 1\right)$ & Hematology control normal & 4.54 & 0.26 & 5.85 \\
\hline \multicolumn{6}{|c|}{ 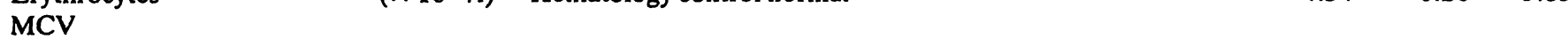 } \\
\hline Leukocytes & $\left(\times 10^{9} / 1\right)$ & Hematology control normal CH-60 Lab. 530; Merz + Dade & 6.53 & 0.66 & 10.2 \\
\hline \multicolumn{6}{|l|}{ Capillary blood } \\
\hline Glucose & $(\mathrm{mmol} / \mathrm{l})$ & Asid 407 liquid & 5.05 & 0.11 & 2.2 \\
\hline \multicolumn{6}{|l|}{ Serum } \\
\hline Total protein & $(g / l)$ & Asid 407 liquid & 67.8 & 0.90 & 1.3 \\
\hline \multicolumn{6}{|l|}{ Electrophores } \\
\hline - Albumin fraction & (1) & Kontrollogen L Behring 3004 & 0.629 & 0.014 & 2.20 \\
\hline$-\gamma$-Globulin fraction & (1) & Kontrollogen L Behring 3004 & 0.159 & 0.010 & 5.97 \\
\hline Bilirubin & $(\mu \mathrm{mol} / 1)$ & Kontrollogen L Behring 3004 & 23.6 & 0.7 & 3.0 \\
\hline Uric acid & $(\mu \mathrm{mol} / \mathrm{l})$ & Kontrollogen L Behring 3004 & 423 & 13 & 3.1 \\
\hline Sọdiụm & (mmol/1) & Asid 497 liquid & 134 & 1.4 & 1.0 \\
\hline Potasssium & $(\mathrm{mmol} / \mathrm{l})$ & Assid 497 liquid & 5.07 & 0.05 & 1.0 \\
\hline Calcium & $(\mathrm{mmol} / \mathrm{l})$ & Asid 497 liquid & 2.4 & 0.025 & 1.0 \\
\hline Chloride & $(\mathrm{mmol} / \mathrm{l})$ & Asid 497 liquid & 104 & 1.1 & 1.0 \\
\hline Phosphorụs & $(\mathrm{mmol} / \mathrm{l})$ & Asid 497 liquid & 1.27 & 0.032 & 2.6 \\
\hline Magnesium & $(\mathrm{mmol} / \mathrm{l})$ & Asid 497 liquid & 1.02 & 0.015 & 1.5 \\
\hline İron & $(\mu \mathrm{mol} / \mathrm{l})$ & Asid 407 liquid & 27.7 & 1.2 & 4.5 \\
\hline Copper & $(\mu \mathrm{mol} / \mathrm{l})$ & Asid 407 liquid & 46.3 & 1.4 & 3.0 \\
\hline Cholesterol & $(\mathrm{mmol} / \mathrm{l})$ & Kontrollogen L Behring 3004 & 3.84 & 0.13 & 3.4 \\
\hline Triglycerides & $(\mathrm{mmol} / \mathrm{l})$ & Kontrollogen L Behring 3004 & 0.75 & 0.05 & 6.9 \\
\hline Creatinine & $(\mu \mathrm{mol} / \mathrm{l})$ & Kontrollogen L Behring 3004 & 137 & 3.5 & 2.6 \\
\hline Urea-N & (mmol/l) & Asid 407 liquid & 2.36 & 0.09 & 4.0 \\
\hline$\gamma$-Glutamyltransferase & $(U / l)$ & Kontrollogen L Behring 3004 & 23.05 & 1.31 & 5.61 \\
\hline Aspartate aminotransferase & $(\mathrm{U} / \mathrm{l})$ & Kontrollogen L Behring 3004 & 35.80 & 1.53 & 4.26 \\
\hline Alanine aminotransferase & $(U / 1)$ & Kontrollogen L Behring 3004 & 30.62 & 1.40 & 4.58 \\
\hline Cholinesterase & $(\mathrm{U} / \mathrm{l})$ & Kontrollogen L Behring 3004 & 3.96 & 0.11 & 3.35 \\
\hline Alkaline phosphatase & $(\mathrm{U} / \mathrm{l})$ & Kontrollogen L Behring 3004 & 144.28 & 4.67 & 3.24 \\
\hline Glutamate dehydrogenase & $(U / 1)$ & Kontrollogen L Behring 3004 & 8.13 & 0.80 & 9.79 \\
\hline Creatine kinase & $(U / 1)$ & Kontrollogen L Behring 3004 & 102.95 & 3.78 & 3.67 \\
\hline
\end{tabular}


ranges considered pathological. The maximum allowable deviation from these assigned values was two between-day standard deviations $\left( \pm 2 \mathrm{~s}_{\mathrm{T}}\right)$. During the course of the investigations the laboratory participated in the interlaboratory surveys of the German Society for Clinical Chemistry and received certificates indicating satisfactory performance for all constituents; in addition, it participated in international interlaboratory surveys, also with satisfactory results. Thus the reliability of the findings is documented.

2.4 Specimen collection with biological influence factors and interference factors in mind

Specimens were collected under standardized conditions in order to eliminate falsification of the results by biological influence factors and interference factors as far as possible $(57,58,5,6)$. Venous blood including EDTA blood and citrate blood was collected between $8 \mathrm{a} . \mathrm{m}$. and $10 \mathrm{a} . \mathrm{m}$. from supine, fasting patients with iron-free needles of adequate diameter. Capillary blood for glucose determination was collected $11 / 2$ hours after a standardized breakfast; the specimen was immediately put into perchloric acid for deproteinization and to prevent glycolysis.

The specimens were stored and transported protected from light in order to avoid changes in the concentration of bilirubin and in creatine kinase catalytic activity. The specimens arrived at the laboratory no later than 2 hours after collection and were then immediately prepared for analysis. If in exceptional cases this was not possible the serum was separated at the collection site and slides prepared for the differential blood count from the EDTA blood. All analyses were performed on the day of specimen collection.

In order to limit the effects of interference factors (6) on the analytical results, the analytical methods used were selected with a view not only to precision and accuracy, but also to specificity. This selection procedure enabled a marked reduction in the effects of interference factors on the analytical results. Because of longitudinal studies currently in progress at our research hospital, it was not possible to switch to the most specific method for certain constituents (e.g. cholesterol).

\section{Results and Discussion}

To answer the questions raised at the outset the analytical results for the alcoholics were compared with reference intervals and the associated location parameters obtained for healthy subjects $(59,60)$. From these comparisons conclusions were drawn about the frequency, direction and magnitude of changes due to alcoholism as a biological influence factor in clinical laboratory investigations.

Each section of results is followed immediately by a discussion of those results.

\subsection{Comparison of the analytical results for alcoholics with the reference intervals ob- tained for "healthy" persons}

The reference intervals used in these comparisons were reference intervals for "healthy" persons obtained with the analytical methods we had used and either determined by us or taken from the literature and checked by us. All of these intervals had proven to be reliable decision limits in recent years.

By definition such a reference interval includes $95 \%$ of the results for healthy persons $(57,60)$. If for a given parameter the lower limit of the reference interval is significantly different from the analytical detection limit, then one can expect that for healthy persons $2.5 \%$ of the values will be outside the lower limit of the reference interval and $2.5 \%$ outside the upper limit. If the lower limit of the reference interval is not significantly different from the detection limit (as in the case of bilirubin and many enzyme activity determinations), then one must expect $5 \%$ of the results to be above the reference interval.

Table 3-1 shows both those parameters for which more than $10 \%$ of the results for the alcoholics were above the reference interval and those for which more than $10 \%$ were below it (as well as a few others). For a few parameters more than $10 \%$ of the results were outside the reference interval on each end.

More than $10 \%$ of the results were above the reference interval for $\gamma$-glutamyltransferase $(78 \%)$, mean corpuscular volume (MCV) $(69 \%)$, alanine aminotransferase $(48 \%)$, aspartate aminotransferase $(38 \%)$, triglycerides $(38 \%)$, glutamate dehydrogenase $(32 \%), \beta$-globulins (22\%), alkaline phosphatase $(13 \%)$ and uric acid (13\%). All of these findings are within the ranges reported in the literature (tab. $0-1)$ for the percentage of alcoholics with elevated values. In our population only $8.5 \%$ of the patients had elevated bilirubin.

More than $10 \%$ of the values were below the reference interval for haemoglobin $(28 \%)$, albumin $(22 \%)$, potassium $(17 \%)$ and haematocrit $(11 \%)$. Decreases in these parameters have also been reported in the literature (tab. 0-1).

More than $10 \%$ of the results were found outside each end of the reference interval for serum iron (24\% above, $28 \%$ below) and cholesterol (22\% above, $22 \%$ below). A drop in cholesterol has not been reported previously in the literature.

3.2 Percentage of analytical results above and below the location parameter for the reference population

It was also conceivable that the values for the alcoholics would have a slight shift as compared with the reference population, but one that did not result in an increase in the number of resultsioutside the ref- 
Tab. 3-1. Comparison of the analytical results for the alcoholics with the reference intervals for healthy persons.

\begin{tabular}{|c|c|c|c|c|c|c|c|}
\hline \multirow[t]{3}{*}{ Constituent } & \multirow[t]{3}{*}{ (Unit) } & \multicolumn{6}{|c|}{ Reference interval } \\
\hline & & \multicolumn{2}{|c|}{ Results below } & \multirow{2}{*}{$\begin{array}{l}\text { Lower } \\
\text { limit }\end{array}$} & \multirow{2}{*}{$\begin{array}{l}\text { Upper } \\
\text { limit }\end{array}$} & \multicolumn{2}{|c|}{ Results above } \\
\hline & & $(\%)$ & $\mathbf{N}$ & & & $\mathbf{N}$ & $(\%)$ \\
\hline Haemoglobin & $(g / l)$ & $(28.4)$ & 23 & 140 & 180 & 2 & (2.5) \\
\hline Haematocrit & (1) & (11.1) & 9 & 0.40 & 0.54 & 2 & (2.5) \\
\hline $\mathrm{MCV}$ & (fI) & $(1.2)$ & 1 & 80 & 96 & 56 & $(69.1)$ \\
\hline Thrombocytes & $\left(10^{9} / 1\right)$ & $(6.2)$ & 5 & 140 & 440 & 2 & $(2.5)$ \\
\hline Total protein & $(g / l)$ & $(0)$ & 0 & 60 & 84 & 2 & (2.4) \\
\hline Albumin fraction & (1) & $(22.0)$ & 18 & 0.55 & 0.75 & 0 & $(0)$ \\
\hline $\begin{array}{l}\text { Globulin fraction } \\
\alpha_{1^{-}}\end{array}$ & & (0) & 0 & 001 & & & \\
\hline $\begin{array}{l}\alpha_{1-}^{-} \\
\alpha_{2^{-}}\end{array}$ & (1) & (0) & $\begin{array}{l}0 \\
0\end{array}$ & $\begin{array}{l}0.01 \\
0.04\end{array}$ & $\begin{array}{l}0.05 \\
0.10\end{array}$ & $\begin{array}{r}4 \\
13\end{array}$ & $(4.9)$ \\
\hline $\begin{array}{l}\alpha_{2-}^{-} \\
\beta-\end{array}$ & (1) & $\begin{array}{l}(0) \\
(0)\end{array}$ & 0 & $\begin{array}{l}0.04 \\
0.06\end{array}$ & 0.14 & $\begin{array}{l}13 \\
18\end{array}$ & $\begin{array}{l}(15.9) \\
(22.0)\end{array}$ \\
\hline$y-$ & $\begin{array}{l}(1) \\
(1)\end{array}$ & (0) & 0 & 0.09 & 0.21 & 8 & $\begin{array}{r}(22.0) \\
(9.8)\end{array}$ \\
\hline Bilirubin & ( $\mu \mathrm{mol} / \mathrm{l})$ & (0) & 0 & 3.4 & 18.8 & 7 & (8.5) \\
\hline Uric acid & $(\mu \mathrm{mol} / \mathrm{l})$ & $(1.2)$ & 1 & 119 & 416 & 11 & $(13.4)$ \\
\hline Sodium & (mmol/l) & $(8.5)$ & 7 & 133 & 159 & 0 & $(0)$ \\
\hline Potassium & $(\mathrm{mmol} / \mathrm{l})$ & $(17.1)$ & 14 & 3.8 & 5.4 & 0 & (0) \\
\hline Calcium & $(\mathrm{mmol} / \mathrm{l})$ & (3.7) & 3 & 2.0 & 2.8 & 0 & $(0)$ \\
\hline Chloride & $(\mathrm{mmol} / \mathrm{l})$ & (9.8) & 8 & 97 & 107 & 0 & (2.4) \\
\hline Phosphorus & $(\mathrm{mmol} / \mathrm{l})$ & $(8.5)$ & 7 & 0.71 & 1.87 & 0 & $(0)$ \\
\hline Magnesium & $(\mathrm{mmol} / \mathrm{l})$ & (9.8) & 8 & 0.7 & 1.0 & 0 & $(0)$ \\
\hline Serum iron & $(\mu \mathrm{mol} / \mathrm{I})$ & $(28.0)$ & 23 & 14.3 & 26.8 & 20 & $(24.4)$ \\
\hline Serum copper & $(\mu \mathrm{mol} / \mathrm{l})$ & $(0)$ & 0 & 10.2 & 30.0 & 5 & $(6.1)$ \\
\hline Cholesterol & $(\mathrm{mmol} / \mathrm{l})$ & $(22.0)$ & 18 & 4.65 & 6.47 & 18 & $(22.0)$ \\
\hline Triglycerides & $(\mathrm{mmol} / \mathrm{l})$ & (4.9) & 4 & 0.84 & 1.94 & 31 & $(37.8)$ \\
\hline Creatinine & $(\mu \mathrm{mol} / \mathrm{l})$ & (2.4) & 2 & 44 & 97 & 2 & $(2.4)$ \\
\hline Urea-N & $(\mathrm{mmol} / \mathrm{l})$ & $(8.5)$ & 7 & 2.1 & 7.9 & 1 & $(1.2)$ \\
\hline$\gamma$-Glutamyltransferase & $(\mathrm{U} / \mathrm{l})$ & (0) & 0 & 6 & 28 & 64 & $(78.0)$ \\
\hline Aspartate aminotransferase & $(U / 1)$ & (0) & 0 & 2 & 20 & 31 & $(37.8)$ \\
\hline Alanine aminotransferase & $(\mathrm{U} / \mathrm{l})$ & (0) & 0 & 2 & 20 & 39 & (47.6) \\
\hline Cholinesterase & $(U / I)$ & $(9.8)$ & 8 & 3 & 8 & 6 & $(7.3)$ \\
\hline Alkaline phosphatase & $(U / 1)$ & (1.2) & 1 & 60 & 200 & 11 & $(13.4)$ \\
\hline Glutamate dehydrogenase & $(\mathrm{U} / \mathrm{l})$ & - & - & - & 4 & 26 & $(31.7)$ \\
\hline Creatine kinase & $(U / I)$ & (0) & 0 & 10 & 70 & 12 & $(14.6)$ \\
\hline
\end{tabular}

erence interval. A check was therefore made of how many analytical results from the alcoholics were on each side of the location parameter for the reference sample group of healthy persons. Table 3-2 shows the cases where there were marked differences. By definition $50 \%$ of the results for a population of healthy persons must be below the location parameter and $50 \%$ above.

For a few constituents there were no clear differences in table $3 \div 1$, but significant differences were found when the results were compared with the location parameter for healthy persons (tab. 3-2). This is the case for the percentage of results above the location parameter for healthy persons for the globulins (74-97\%), calcium (73\%) and serum copper (70\%). The elevations in serum copper and in the globulins have been reported in the literature. The increase in calcium following excessive alcohol consumption over several days has also been observed (18).
Furthermore, there are marked differences in the percentage of results below the location parameter for sodium $(99 \%)$, phosphorus $(96 \%)$, magnesium $(91 \%)$ and urea-N $(80 \%)$. There are no reports of decreases in sodium in the literature and only one of decreases in urea (22), whereas low phosphate and magnesium values have been observed repeatedly.

A discussion of the pathobiochemical foundations for the changes in haematological and clinical chemical parameters in alcoholics observed in the present study is unfortunately beyond the scope of this paper. One point is clear, however: It is not possible with the data obtained in this study to identify alcohol abuse on the basis of one parameter, i.e. using only a single clinical laboratory finding. This observation led to a multivariate evaluation of the analytical results from alcoholics and non-alcoholics with the goal of detecting and excluding alcoholism. The results of that evaluation are reported elsewhere (61). 
Tab. 3-2. Comparison of the analytical results for the alcoholics with the location parameter for the reference population of healthy persons.

A constituent is listed only if significantly more of the analytical results for the alcoholics were above or below the location parameter for the results for healthy persons than in the reference group itself.

\begin{tabular}{|c|c|c|c|c|c|c|c|}
\hline \multirow[t]{3}{*}{ Constituent } & \multirow[t]{3}{*}{ (Unit) } & \multicolumn{6}{|c|}{ Analytical results for the alcoholics } \\
\hline & & \multicolumn{2}{|l|}{ Below } & \multirow{2}{*}{$\begin{array}{l}\text { Location } \\
\text { parameter } \\
\text { for healthy } \\
\text { persons }\end{array}$} & \multicolumn{2}{|c|}{ Above or the satrie as } & \multirow{2}{*}{ 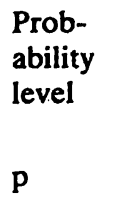 } \\
\hline & & $(\%)$ & $\mathbf{N}$ & & $\mathbf{N}$ & $(\%)$ & \\
\hline Haemoglobin & $(g / l)$ & $(77.8)$ & 63 & 160 & 18 & $(22.2)$ & $<0.001$ \\
\hline Haematocrit & (1) & $(66.7)$ & 54 & 0.47 & 27 & (33.3) & $<0.01$ \\
\hline MCV & (fl) & $(3.7)$ & 3 & 88 & 78 & $(96.3)$ & $<0.001$ \\
\hline Total protein & $(g / 1)$ & $(35.4)$ & 29 & 72 & 53 & $(64.6)$ & $<0.01$ \\
\hline \\
\hline Albumin fraction & (1) & $(97.6)$ & 80 & 0.65 & 2 & $(2.4)$ & $<0.001$ \\
\hline \multicolumn{8}{|l|}{ Globulin fraction } \\
\hline$\alpha_{1^{-}}$ & (1) & $(2.4)$ & 2 & 0.03 & 80 & $(97.6)$ & $<0.001$ \\
\hline$\alpha_{2-}$ & (1) & $(7.3)$ & 6 & 0.07 & 76 & (92.7) & $<0.001$ \\
\hline$\beta-$ & (1) & $(1.2)$ & 1 & 0.10 & 81 & $(98.8)$ & $<0.001$ \\
\hline$\gamma-$ & (1) & $(25.6)$ & 21 & 0.15 & 61 & $(74.4)$ & $<0.001$ \\
\hline Uric acid & $(\mu \mathrm{mol} / \mathrm{l})$ & (19.5) & 16 & 268 & 66 & $(80.5)$ & $<0.001$ \\
\hline Sodium & $(\mathrm{mmol} / \mathrm{l})$ & (98.8) & 81 & 146 & 1 & $(1.2)$ & $<0.001$ \\
\hline Potassium & $(\mathrm{mmol} / \mathrm{l})$ & $(90.2)$ & 74 & 4.6 & 8 & $(9.8)$ & $<0.001$ \\
\hline Calcium & $(\mathrm{mmol} / \mathrm{l})$ & $(16.8)$ & 22 & 2.4 & 60 & $(73.2)$ & $<0.05$ \\
\hline Thrombocytes & $\left(10^{9} / 1\right)$ & $(64.2)$ & 5 & 290 & 29 & $(35.8)$ & $<0.05$ \\
\hline Chloride & $(\mathrm{mmol} / \mathrm{l})$ & $(39.0)$ & 32 & 102 & 50 & $(61.0)$ & $<0.05$ \\
\hline Phosphorus & $(\mathrm{mmol} / \mathrm{l})$ & (96.3) & 79 & 1.29 & 3 & $(3.7)$ & $<0.001$ \\
\hline Magnesium & $(\mathrm{mmol} / \mathrm{l})$ & (91.5) & 75 & 0.87 & 7 & $(8.5)$ & $<0.001$ \\
\hline Serum copper & $(\mu \mathrm{mol} / \mathrm{l})$ & $(29.3)$ & 24 & 18.1 & 58 & $(70.7)$ & $<0.01$ \\
\hline Triglycerides & $(\mathrm{mmol} / \mathrm{l})$ & $(30.5)$ & 25 & 1.39 & 57 & $(69.5)$ & $<0.001$ \\
\hline Urea-N & $(\mathrm{mmol} / \mathrm{l})$ & $(80.5)$ & 66 & 5.0 & 16 & (19.5) & $<0.001$ \\
\hline Creatinine & $(\mu \mathrm{mol} / \mathrm{l})$ & $(46.3)$ & 38 & 66 & 44 & $(53.7)$ & \\
\hline$\gamma$-Glutamyltransferase & $(\mathrm{U} / \mathrm{l})$ & $(4.0)$ & 4 & 17 & 78 & $(95.1)$ & $<0.001$ \\
\hline Aspartate aminotransferase & $(\mathrm{U} / \mathrm{l})$ & $(13.4)$ & 11 & 12 & 71 & $(86.6)$ & $<0.001$ \\
\hline Alanine aminotransferase & $(U / 1)$ & $(3.7)$ & 3 & 9 & 79 & $(96.3)$ & $<0.001$ \\
\hline Creatine kinase & $(U / I)$ & $(63.4)$ & 52 & & 30 & $(36.6)$ & $<0.05$ \\
\hline Alkaline phosphatase & $(U / 1)$ & $(35.4)$ & 29 & 5.5 & 53 & $(64.6)$ & $<0.01$ \\
\hline
\end{tabular}

\section{Conclusions}

Excessive alcohol consumption in men in the extreme form of alcoholism is a frequently observed biological influence factor for many clinical chemical parameters and one that must be taken into consideration in the assessment of analytical results.

The following can now be said with reference to the questions raised initially:

1. Alcoholism is a biological influence factor with respect to the following clinical chemical and haematological parameters: $\boldsymbol{\gamma}$-glutamyltransferase, mean corpuscular volume (MCV), alanine aminotransferase, triglycerides, aspartate aminotransferase, glutamate dehydrogenase, serum iron, haemoglobin, creatine kinase, cholesterol, potässium, albumin, uric acid and $\gamma$-globulins (tab. 3-1).

2. There is a shift in the distribution of the analytical results for alcoholics only within the reference interval for urea $(80 \%)$, magnesium $(91 \%)$ and sodium $(98 \%)$. The percentage of alcoholics with results below and above the location parameter of the reference sample group are given in table 3-2 in parentheses.

3. The effects of the biological influence factor "excessive alcohol consumption" in terms of both frequency and magnitude are so great that the possible presence of excessive consumption must be considered expressly when selecting a sample from a ref- 
erence population of healthy persons for the establishment of reference intervals and the associated location parameters.

4. It is therefore advisable to exclude all alcoholics from a reference sample group to be used for the determination of reference intervals for healthy persons.

5. The biological influence factor "excessive alcohol consumption" must also always be taken into consideration in the medical assessment of the parameters listed under 1 . above.

6. The results of this study indicate that it is impossible to detect and exclude excessive alcohol consumption on the basis of a single clinical chemical parameter, i.e. using only one finding.

A multivariate assessment of the data is reported elsewhere (61).

\section{References}

1. Rosalki, S. B. \& Rau, D. (1972)

Serum $\gamma$-glutamyl transpeptidase activity in alcoholism.

Clin. Chim. Acta 39, 41-47.

2. Rosalki, S. B. (1977)

Enzyme tests for alcoholism.

Rev. Epidém. Santé Publ. 25, 147-158.

3. Wu, A., Chanarin, I. \& Levi, A. J. (1974)

Macrocytosis of chronic alcoholism.

Lancet $I, 829-831$.

4. Wietholtz, H. \& Colombo, J. P. (1976)

Das Verhalten der $\gamma$-Glutamyltranspeptidase und anderer Leberenzyme im Plasma während der Alkohol-Entziehungskur.

Schweiz. Med. Wochenschr. 106, 981-987.

5. Guder, W. G. (1980)

Einflußgrößen und Störfaktoren bei klinisch-chemischen Untersuchungen.

Internist $21,533-542$.

6. Stamm, D. (1982)

A new concept for quality control of clinical laboratory investigations in the light of clinical requirements and based on reference method values.

J. Clin. Chem. Clin. Biochem. 20, 817-824.

7. Edwards, G., Orfford, J., Egert, S., Guthrie, S., Hawker, A., Hensman, C., Mitchesson, M., Oppenheimer, E. \& Taylor, C. (1977)

Alcoholism: A controlled trial of "treatment" and "advice". J. Stud. Alc. 38, 1004-1031.

8. Feuerlein, W., Ringer, Ch., Kụ̈fner, H. \& Antons, K. (1977) Diagnose des Alkoholismus. Der Münchner AlkoholismusTest (MALT).

Münch. Med. Wochenschr. 119, 1275-1282.

9. Feuerlein, W., Küfner, H., Ringer, Ch. \& Antons, K. (1979) Münchner Alkoholismustest (MALT).

Beltz Verlag, Weinheim.

10. Böttiger, L. E., Carlson, L. A., Hultmann, E. \& Romanus, V. (1976)

Serum lipids in alcoholics.

Acta Med. Scand. 199, 357-361.

\section{Acknowledgments}

The extensive project reported here would not have been possible without the efficient cooperation of three departments within the Max-Planck-Institut für Psychiatrie.

The patients were selected and examined by Dr. Sigrid Seidel and Dr. V. Geiger of the Psychiatric Outpatient Department. The clinical chemical and haematological investigations were performed in the routine laboratory of the Department of Clinical Chemistry. Special thanks are due to the head technologist, Ms. Liselotte Hofmann, to Ms. Elisabeth Stiegler (née Roesch) and to all the other laboratory technicians.

Ms. Ingrid Bickert and Ms. Eva Müller (Department of Biostatistics) carried out the data processing, compiled the tables and prepared the diagrams with great care. Ms. Elisabeth Geirhos and Ms. Ursula Grau prepared the extensive list of references and numerous drafts of the manuscript with great attention to accuracy and detail.

Professors Ellen Schmidt and Johannes Büttner of Hannover were kind enough to discuss the results and their evaluation with us; they also provided us with valuable suggestions for the future validation of our findings.

We would like to express our thanks to all who contributed to this project.

11. Wallerstedt, S. \& Olsson, R. (1978)

Changes in "routine laboratory tests" during abstinence after heavy alcohol consumption in chronic alcoholics.

Acta Hepato-Gastroenterol. 25, 13-19.

12. Lindenbaum, J. (1974)

Hematologic effects of alcohol. In: The Biology of Alcoholism, Vol. 3: Clinical Pathology (Kissin, B. \& Begleiter, H. eds.), Plenum Press, New York, London, pp. 461-480.

13. Ryback, R. S., Eckardt, M. J. \& Pautler, C. P. (1980) Biochemical and hematological correlates of alcoholism. Res. Commun. Chem. Path. Pharmacol. 27, 533-550.

14. Wisser, H. \& Knoll, E. (1980)

Die diagnostische Wertigkeit von labormedizinischen Parametern bei Alkoholismus und Exposition mit halogenierten aliphatischen Kohlenwasserstoffen.

Ärztl. Lab. 26, 78-82.

15. Heidemann, E., Nerke, O. \& Waller, H. D. (1981) Alkoholtoxische Veränderungen der Hämatopoiese. Klin. Wochenschr. 59, 1303-1312.

16. Goebel, K.-M. (1978) Alkoholbedingte hämatologische Störungen. Internist 19, 110-115.

17. Bode, J. Ch. (1981)

Die alkoholische Hepatitis, ein Krankheitsspektrum. Internist 22, 536-545.

18. Friedman, R. B., Anderson, R. E., Entine, S. M. \& Hirshberg, S. B. (1980)

Effects of diseases on clinical laboratory tests.

Clin. Chem. 26, 1D-476D.

19. Drum, D. E., Goldman, P. A. \& Jankowski, C. B. (1981) Elevation of serum uric acid as a clue to alcohol abuse. Arch. Intern. Med. 141, 477-479.

20. Saunders, J. B., Beevers, D. G. \& Paton, A. (1981) Alcohol-induced hypertension. Lancet II, 653-656.

21. Baumgartner, H. P. \& Filippini, L. (1977) Alkoholinduzierte Hyperlipoproteinämien. Schweiz. Med. Wochenschr. 107, 1406-1411. 
22. Bagrel, A., d'Houtaud, A., Gueguen, R. \& Siest, G. (1979) Relations between reported alcohol consumption and certain biological variables in an "unselected" population.

Clin. Chem. 25, 1242-1246.

23. Westwood, M., Cohen, M. I. \& McNamara, H. (1978) Serum $\gamma$-glutamyl transpeptidase activity: A chemical determinant of alcohol consumption during adolescence. Pediatrics 62, 560-562.

24. Mills, P. R., Spooner, R. J., Russell, R. I., Boyle, P. \& Mac Sween, R. N. M. (1981)

Serum glutamate dehydrogenase as a marker of hepatocyte necrosis in alcoholic liver disease.

Brit. Med. J. 283, 754-755.

25. Rosalki, S. B. (ed.) (1978)

New Pathways in Laboratory Medicine.

Hans Huber Publishers, Bern, Stuttgart, Vienna.

26. Schmidt, E. (1975)

Medikamentös bedingte $\gamma$-GT-Aktivitätszunahme.

Dtsch. Med. Wochenschr. 100, 443-444.

27. Stamm, D., Hansert, E. \& Feuerlein, W. (in press)

Der Trend einer klinisch-chemischen Kenngröße als Bewertungskriterium.

28. van Kampen, E. J. \& Zijlstra, W. G. (1965)

Determination of hemoglobin and its derivatives.

Advanc. Clin. Chem. 8, 141-187.

29. Leybold, K. \& Grabener, E. (1976)

Praxis-Laboratorium, Georg Thieme Verlag, Stuttgart.

30. Schmidt, F. H. (1961)

Die enzymatische Bestimmung von Glucose und Fructose nebeneinander.

KJin. Wochenschr. 39, 1244-1247.

31. Weichselbaum, T. E. (1946)

An accurate and rapid method for the determination of proteins in small amounts of blood serum and plasma.

Amer. J. Clin. Pathol. (Technical Bulletin) 16, 40-49.

32. Müller, B. \& Stamm, D. (1973)

Experiences with a protein standard in clinical chemistry.

In: Organisation des Laboratoires - Biologie Prospective (Siest, G., ed.). L'Expansion scientifique Française, Paris, pp. 543-546.

33. Thomas, L. (1981) Eiweiß-Elektrophorese.

Urban \& Schwarzenberg, Munich, Vienna, Baltimore.

34. Jendrassik, L. \& Gróf, P. (1938)

Vereinfachte photometrische Methoden zur Bestimmung des Blutbilirubins.

Biochem. Z. 297, 81-89.

35. Kageyama, N. (1971)

A direct colorimetric determination of uric acid in serum and urine with uricase-catalase system.

Clin. Chim. Acta 31, 421-426.

36. Hansen, J. L. \& Freier, E. F. (1967)

The measurement of serum magnesium by atomic absorption spectrophotometry.

Amer. J. Med. Technol. 33, 1-9.

37. Trinder, P. (1956)

Improved determination of iron in serum.

J. Clin. Pathol. 9, 170-172.

38. Zak, B. (1958)

Simple procedure for the single sample determination of serum copper and iron.

Clin. Chim. Acta, 3, 328-334.

39. Watson, D. (1960)

A simple method for the determination of serum cholesterol

Clin. Chim. Acta 5, 637-643.

40. Eggstein, M. \& Kreutz, F. H. (1966)

Eine neue Bestimmung der Neutralfette im Blutserum und Gewebe: I. und II. Mitteilung.

Klin. Wochenschr. 44, 262-267; 267-273.

41. Knoll, E. \& Stamm, D. (1970)

Spezifische Kreatininbestimmung im Serum.

Z. Klin. Chem. Klin. Biochem. 8, 582-587.
42. Fawcett, J. K. \& Scott, J. E. (1960)

A rapid and precise method for the determination of urea. J. Clin. Pathol. 13, 156-159.

43. Szasz, G. (1974)

$\gamma$-Glutamyltranspeptidase.

In: Methods of Enzymatic Analysis (Bergmeyer, H. U., 'ed.), 2nd English edition, translated from the 3rd German edition, Vol. 2. Verlag Chemie, Weinheim; Academic Press, New York, London, pp. 715-720.

44. Empfehlungen der Deutschen Gesellschaft für Klinische Chemie (1970), Standardisierung von Methoden zur Bestimmung von Enzymaktivitäten in biologischen Flüssigkeiten. $Z$. Klin. Chem. Klin. Biochem. 8, 658-659 (English translation pp. 659-660).

45. Empfehlungen der Deutschen Gesellschaft für Klinische Chemie (1972), Standardisierung von Methoden zur Bestimmung von Enzymaktivitäten in biologischen Flüssigkeiten: Experimentelle Begründung der optimierten Standard-Bedingungen. Z. Klin. Chem. Klin. Biochem. 10, 182-192 (English translation pp. 281-291).

46. Empfehlungen der Deutschen Gesellschaft für Klinische Chemie (1974), Standardisierung von Methoden zur Bestimmung von Enzymaktivitäten in biologischen Flüssigkeiten: Experimentelle Begründung der optimierten Standard-Bedingungen. Ergänzungen zur Standard-Methode zur Bestimmung der Aktivität der Glụtamat-Dehydrogenase (GLDH). Z. Klin. Chem. Klin. Biochem. 12, 391 (English translation p. 392).

47. Empfehlungen der Deutschen Gesellschaft für Klinische Chemie (1977), Standardisierung von Methoden zur Bestimmung von Enzymaktivitäten in biologischen Flüssigkeiten: Standard-Methode zur Bestimmung der Aktivität der Creatin-Kinase. Uberarbeitete Fassung von 1976. J. Clin. Chem. Clin. Biochem. 15, 249-254 (English translation pp. 255260).

48. Knedel, M. \& Böttger, R. (1967)

Eine kinetische Methode zur Bestimmung der Aktivität der Pseudocholinesterase (Acylcholin-acylhydrolase 3.1.1.8).

Klin. Wochenschr. 45, 325-327.

49. Szász, G. (1968)

Cholinesterase Bestimmung in Serum mit Acetyl- und Butyrylthiocholin als Substrat.

Clin. Chim. Acta 19, 191-204.

51. Szasz, G., Weimann, G., Stähler, F., Wahlefeld, A.-W. \& Persijn, J.-P. (1974)

New substrates for measuring $\gamma$-glutamyl transpeptidase activity.

Z. Klin. Chem. Klin. Biochem. 12, 228.

52. Büttner, H. (1967)

Statistische Qualitätskontrolle in der klinischen Chemie.

Z. Klin. Chem. Klin. Biochem. 5, 41-48.

53. Stamm, D. (1972)

Qualitätskontrolle klinisch=chemischer Analysen. Georg Thieme Verlag, Stuttgart.

54. Guidelines of the Medical Society of West Germany for statistical quality control and collaborative surveys (1974). Mitteilungen der Deutschen Gesellschaft für Klinische Chemie 3, 33-36. Originally published in German in Deutsches Ärzteblatt (1971), 68, 2228-2231.

55. Regulations and explanations regarding the implementation of the guidelines of the Medical Society of West Germany (1974). Mitteilungen der Deutschen Gesellschaft für Klinische Chemie 3, 36-43. Originally published in German in Deutsches Ärzteblatt (1974), 71, 961-965.

56. Hansert, E. \& Stamm, D. (1980)

Determination of assigned values in control specimens for internal accuracy control and for interlaboratory surveys Evaluation of 200 different lots with identical experimental design: Experiences and conclusions.

J. Clin. Chem. Clin. Biochem. 18, 461-490. 
57. Büttner, H., Hansert, E. \& Stamm, D. (1974) Statistical analysis, control and assessment of experimental results.

In: Methods of Enzymatic Analysis (Bergmeyer, H. U., ed.), 2nd English edition, translated from the 3rd German edition, Vol. 1. Verlag Chemie, Weinheim; Academic Press, New York, London, pp. 318-395.

58. Young, D. S., Pestaner, L. C. \& Gibberman, V. (1975) Effects of drugs on clinical laboratory tests.

Clin. Chem. 21, 1D-432D.

59. Gräsbeck, R., Siest, G., Wilding, P., Williams, G. Z. \& Whitehead, T. P. (1978)
Provisional recommendations on the theory of reference values (1978) Part 1. The concept of reference values. Clin. Chim. Acta 87, F459-F465; reprinted in J. Clin. Chem. Clin. Biochem. 17, 337-339 (1979) and Clin. Chem. 25, 1506-1508 (1979).

60. Gräsbeck, R. \& Alström, T. (eds.) (1981)

Reference Values in Laboratory Medicine. John Wiley \& Sons, Chichester, New York, Brisbane, Toronto, Singapore.

61. Stamm, D., Hansert, E. \& Feuerlein, W. (1984)

Detection and exclusion of alcoholism in men on the basis of clinical laboratory findings.

J. Clin. Chem. Clin. Biochem. 22, 79-96.

Prof. Dr. Dr. Dankwart Stamm Leiter der Abteilung für Klinische Chemie Max-Planck-Institut für Psychiatrie Kraepelinstraße 10

D-8000 München 40 
- 